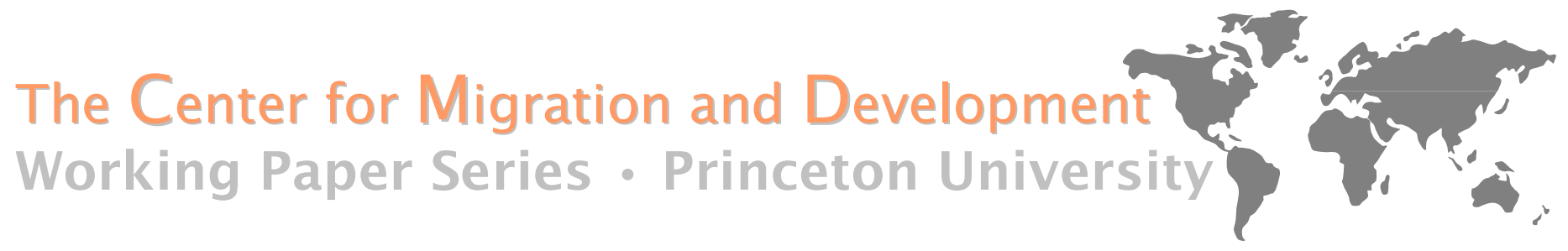

Migration and Social Change:

Some Conceptual Reflections

by

Alejandro Portes

Princeton University

August 2008

CMD Working Paper \#08-04 


\title{
Migration and Social Change: Some Conceptual Reflections ${ }^{1}$
}

\author{
by \\ Alejandro Portes \\ Princeton University
}

August 2008

\footnotetext{
${ }^{1}$ Keynote address to the conference on "Theorizing Key Migration Debates”, Oxford University, July 1, 2008. I thank Erik Vickstrom for his assistance with library research for this essay and Stephen Castles and Raul DelgadoWise for their comments. I also thank Andres Tornos for inspiring ideas that I have sought to incorporate in the paper. Responsibility for the contents, however, is exclusively mine.
} 
Examining the multiple ways in which migration relates to social change is a daunting task. It requires, first of all, defining what social change is and, secondarily, delimiting the scope of analysis to certain types of migration and not others. The greatest dangers that I envision in this enterprise are, first, getting lost in generalities of the "social change is ubiquitous" kind and, second, attempting to cover so much terrain as to lose sight of analytic priorities and of major, as opposed to secondary, causal linkages. I seek to avoid these dangers by discussing first the concept of social change, second identifying the types of migration to be considered, and third examining the major factors that link one to another. I conclude the paper with four theoretical and methodological considerations suggested by the analysis that may guide future work in this field.

\section{The Concept of Social Change}

Since time immemorial, thinkers and writers on social affairs have fairly well divided among those who focused on stability and order and those that privileged transformation. Among the Greeks, Parmenides and the Eleatics denied the possibility of movement and stressed the permanence and unity of beings, while Heraclitus' famous metaphor of the never-the-same river illustrated being as eternal becoming (Maritain 1960; 1963).

Medieval scholastic thinkers were of one voice in envisioning the terrestrial social order as a reflection of the immutable heavens and, hence, of a natural hierarchy in which everyone was born with a defined place and calling and in which every humanly-created disruption of time-sanctioned norms and patterns of conduct was to be condemned as a violation of the divine design. The only possible society was that which already existed (Maritain 1963; Balmes 1961; Phelan 1969). It was necessarily for thinkers of the Enlightenment to toss off the one-to-one 
correspondence between celestial and earthly societies - a major intellectual achievement at the time - in order to begin to contemplate the possibility that other ways of organizing life-incommon could exist. The French Revolution, arguably the defining event of modern times, put these ideas into practice by showing how this could be done, confining divine rights in the process to the dustbin of history (Ortega y Gasset 1958; Dobb [1947] 1963).

The French Revolution shifted the course of Western social thought from stasis to change. The discipline of sociology, a child of the Enlightenment was to make its business to trace the process by which European societies had shifted from Theological and Philosophical Thought to Scientific Thought (Comte); from Mechanic to Organic Solidarity (Durkheim); from Gemeinshaft to Gesellshaft (Tonnies); and from tradition to modernity (Simmel; Spencer). Philosophy and later political economy underwent a parallel re-orientation with the difference that, in addition to describing the stages of societal evolution, as most sociologists were doing, they thought to uncover the master mechanism that accounted for historical change (Maritain 1960; Ortega y Gasset 1958; Mandel 1978).

Philosophers found the key in the concept of dialectics where the reigning Idea did battle with a rising Anti-Thesis with the struggle eventually giving way to a new Synthesis that, in turn, became hegemonic provoking a new opposite thesis ad infinitum. Trained as a philosopher, Marx adopted this Hegelian master concept but then proceeded to turn his master "on his head" by arguing that it was not ideas, but material forces of production that clashed repeatedly, giving rise to new and previously inconceivable forms of economic and social organization (Marx [1848] 1964; Dahrendorf 1959). Dialectical materialism became the theoretical anchoring point for a school of thought in sociology and political economy influential to our day (Dobb [1947] 1963; Bourdieu 1990; Merton 1968). 
With the wisdom of hindsight, we can see that the concept of dialectics, ideal or material, is less a causal master mechanism than a meta-theoretical assumption pitched at such a high level of abstraction as to render it unfalsifiable. It is certainly possible to construct dialectical narratives a posteriori but, in contemporary society, it is difficult to specify what the thesis and antithesis might be or when the awaited synthesis will burst into the scene. For this reason, Hegelian and Marxist dialectics are ultimately “sensitizing notions”, general perspectives whose value lies in highlighting certain aspects of reality as worthy of attention, but without identifying concrete causal sequences or mechanisms (Weber [1904] 1949; Stinchcombe 1968).

Sociology had to await the advent of the Parsonian Synthesis in the twentieth century to restore some balance between theories of social stability and change and, in the process, return to some of the long-forgotten themes of medieval scholastic thought. Parsons’ pattern variables did repeat the familiar nineteenth century exercise about the stages of societal evolution, this time breaking them down into five subsets - from "ascription/achievement” to “particularism/universalism” (Parsons 1951). However, the bulk of his intellectual project was to construct a conceptual edifice isomorphic with society itself and where "pattern maintenance" and "equilibrium” were paramount. Social change in this system was relegated to a marginal place where internally-driven transformation occurred only incrementally and where external "shocks" on the system were to be decisively confronted in order to restore equilibrium (Parsons 1951; Parsons and Smelser 1956; Coser 1956; Dahrendorf 1959).

Much of contemporary social theorizing, arguably with the exception of post-modernism and other nihilist currents, consists of a continuing debate between post-Marxists and postParsonian advocates or, what is the same, between latter-day enactors of the historical contest between ideas of stability and change (Collins 1988; Bourdieu 1990; Kincaid 1996). Leaving 
these debates aside, we may ask what these centuries-old traditions have bequeathed us in the way of useful tools for the analysis of contemporary events. In other words, what have we learned? At the broadest level, such lessons may be synthesized in five points:

1. Stability and change co-exist. While it is true that "change is ubiquitous", it is also the case that it could not happen if there was nothing tangible, no established structure to "change" in the first place.

2. Sources of change are multiple and are not limited to the social system's internal dialectics.

3. Effects of social change are similarly diverse. They can be organized in a hierarchy of “micro-processes” affecting individuals and their immediate surroundings; “meso-processes” affecting entire communities and regions; and “macro-processes” affecting full societies and even the global system.

4. Change at each of these levels must be similarly prioritized into processes occurring "at the surface" and yielding only marginal modifications of the social order and those producing core systemic changes of the kind identified in everyday discourse as “revolutionary.”

5. Stability is reflected, at the visible level of social life, in existing institutions and the social organizations that they underlie. Stabilizing major processes of social change consists precisely in institutionalizing their consequences.

These five general points require additional explanation. 


\section{Culture and Social Structure: A Conceptual Primer}

I borrow here from previously published essays on the definition of institutions and their positioning, relative to other elements of social life (Portes 2006; Portes and Smith 2008). This is done in order to clarify the qualitatively different levels at which social change can take place and the scope and the implications of these differences. From its classical beginnings, modern Sociology developed a central distinction, consolidated by the mid-twentieth century, between culture and social structure. The distinction is analytical because only human beings exist in reality, but it is fundamental to understand both the motives for their actions and their consequences. Culture is the realm of values, cognitive frameworks, and accumulated knowledge. Social structure is the realm of interests, individual and collective, backed by different amounts of power. This symbolic distinction provides the basis for analyzing the difference between what "ought to be" or "is expected to be" and what actually "is" in multiple social contexts (Merton 1936, 1968a).

The diverse elements that compose culture and social structure can be arranged in a hierarchy of causative influences from "deep” factors, often concealed below everyday social life but fundamental for its organization, to "surface" phenomena, more mutable and more readily evident. Language and values are the deep elements of culture, the first as the fundamental instrument of human communication and the second as the motivating force behind principled action, individual or collective (Durkheim [1897] 1965; Weber [1904] 1949). Values are deep culture because they are seldom invoked in the course of everyday life. The latter occurs, for the most part, in a habitual state with values coming to the fore only in exceptional circumstances. Yet, they underlie, and are inferred from, aspects of everyday behavior which are the opposite of unrestrained self-interest. 
Values are not norms and the distinction is important because the first represent general moral principles and the second concrete directives for action (Newcomb et. al. 1965; MacIver and Page [1949] 1961). Values underlie norms which are rules that prescribe the "do's" and “don'ts” of individual everyday conduct. These rules can be formal and codified into constitutions and laws, or they can be implicit and informally enforced. The concept of norms has been used, at least since Durkheim ([1901] 1982), to refer to this restraining element of culture. The significance of the values embodied into norms is reflected in practice in the level of sanctions attached to the latter. Thus life in prison or the death penalty awaits those found guilty of deliberate murder, while loud protest and insulting remarks may be the lot of those seeking to sneak ahead of a queue (Cooley 1902, 1912; Simmel [1908] 1964; Goffman 1959).

Norms are not free-floating, but come together in organized bundles known as roles. Roles are generally defined as the set of behaviors prescribed for occupants of particular social positions (Linton 1945; Newcomb 1950: Ch. 3). Well-socialized persons shift from role to role effortlessly and often unconsciously as part of their daily routines. The normative blueprints that constitute a role generally leave considerable latitude for their individual enactment. Thus the role of "physician" or "mother" may be performed in very different ways by individual occupants, while still conforming to its normative expectations.

An extensive literature in both sociology and social psychology has analyzed roles as the building blocks of social life and as one of the lynchpin concepts linking the symbolic world of culture to real social structures. The same literature examined such dynamics as the "role set" enacted by given social actors and the "role conflict" or "role strain" created when normative expectations in an actor's role sets contradict each other (Cottrell 1933; Linton 1945; Merton 1957; Goffman 1959, 1961; Goode 1960). Along with normative expectations, roles also 
embody an instrumental repertoire of skills necessary for their proper enactment. Language is the fundamental component of this repertoire for, without it, no other skills can be enacted. These cultural "tool kits" also contain, however, many other elements - from scientific and professional know-how to demeanor, forms of expressions, manners, and general savoir faire suitable for specific social occasions. In the modern sociological literature, these elements are referred to by the concepts of cultural capital or "skills repertoires" (Bourdieu 1979; 1984; Swidler 1986; Zelizer 2005).

Parallel to the component elements of culture run those of social structure. These are not made up of moral values or generalized "do's" and "don'ts" flowing from them, but by the specific and differentiated ability of social actors to compel others to do their bidding. This is the realm of power which, like that of values, is situated at the "deep" level of social life influencing a wide variety of outcomes, albeit in different ways. Weber's classic definition of power as the ability of an actor to impose his/her will despite resistance is still appropriate, for it highlights the compulsory and coercive nature of this basic element of social structure. It does not depend on the voluntary consent of subordinates and, for some actors and groups to have it, others must be excluded from access to power-conferring resources (Weber [1922] 1947; Veblen [1899] 1998; Mills 1959). While values motivate or constrain, power enables. Naturally, elites in control of power-conferring resources seek to stabilize and perpetuate their position by molding values so that the mass of the population is persuaded of the "fairness" of the existing order. Power thus legitimized becomes authority in which subordinates readily acquiesce to their position (Weber [1922] 1947; Bendix 1962: Chs. 9-10).

In Marx’ classic definition, power depends on control of the means of production, but in the modern post-industrial world this definition appears to be too restrictive (Marx [1939] 1970; 
[1867] 1967, Part VII). Power is conferred as well by control of the means of producing and appropriating knowledge, by control of the means of diffusing information, and by the more traditional control of the means of violence (Weber [1922] 1947; Wright 1980, 1985; Poulantzas 1975). In the Marxist tradition, a hegemonic class is one which has succeeded in legitimizing its control of the raw means of power, thus transforming it into authority (Gramsci [1927-33] 1971; Poulantzas 1975).

Like values are embodied in norms, power differentials give rise to social classes - large aggregates whose possession or exclusion from resources lead to varying life chances and capacities to influence the course of events. Classes need not be subjectively perceived by their occupants in order to be operative, for they underlie the obvious fact that people in society are ranked according to what they can or cannot do or, alternatively, by how far they are able to implement their goals when confronted with resistance (Wright 1985; Wright and Perrone 1976; Poulantzas 1975). Class position is commonly associated with wealth or its absence, but it is also linked to others power-conferring resources such as expertise or the "right" connections with others (Hout et. al. 1993; Bourdieu 1984, 1990; Portes 2000a). As emphasized by Bourdieu (1985) dominant classes generally command a mix of resources that includes not only wealth, but also ties to influential others (social capital), and the knowledge and style to occupy highstatus positions (cultural capital).

The deep character of power seldom comes to the surface of society for, as seen previously, its holders aim to legitimize it in the value system in order to obtain the consent of the governed. For the same reason, class position is not readily transparent and it is a fact, repeatedly verified by empirical research, that individuals with very different resources and life chances frequently identify themselves as members of the same "class" (Hout et. al. 1993; 
Grusky and Sorensen 1998). Legitimized power (authority) produces status hierarchies which is how most social actors actually perceive the underlying structure of power and how they classify themselves. In turn, status hierarchies are commonly linked to the enactment of occupational roles defined by differential bundles of norms and skill repertoires (MacIver and Page [1949] 1961; Newcomb et. al. 1965: 336-341; Linton 1945).

These various elements of culture and social structure, placed at different levels of causal importance and visibility, occur simultaneously and appear, at first glance, like an undifferentiated mass. Their analytic separation is required, however, for the proper understanding of social phenomena, including social change. Not everything is "constraints on behavior”, as currently popular neo-institutionalist analyses argue (North 1990; Greif 2006); some elements constrain, others motivate, and still others enable. The conceptual framework outlined thus far is summarized in Figure 1. As the citations accompanying the text suggest, this framework is not new or improvised, but forms part of an intellectual legacy dating back to the sociology classics and frequently neglected today.

Figure 1 about here

As shown in Figure 1, status with attached roles do not generally occur in isolation, but as part of social organizations. Organizations, economic and otherwise, are what social actors normally inhabit in the routine course of their lives and they embody the most readily visible manifestations of the underlying structures of power (Powell 1990; DiMaggio 1990; Granovetter 2001). Institutions represent the symbolic blueprint for organizations; they are the set of rules, written or informal, governing relationships among role occupants in social organizations like 
the family, the schools, and the other major areas of social life: the polity, the economy, religion, communications and information, and leisure (MacIver and Page [1949] 1961; Merton 1968c; North 1990; Hollingsworth 2002).

This definition of institutions is in closer agreement with everyday uses of the term, as when one speaks of “institutional blueprints”. Its validity does not depend, however, on this overlap, but on its analytic utility. The distinction between organizations and institutions is there to highlight an important mechanism of everyday social change that would be otherwise obscured. No doubt, as Douglass North (1990) puts it, “institutions matter”, but they are also subject to what Granovetter $(1985,1992)$ referred to as “the problem of embeddedness”; namely, that the human exchanges that institutions seek to control and guide in turn affect the same institutions. This is why formal goals and prescribed institutional hierarchies come to differ with how organizations operate in reality (Dalton 1959; Morrill 1991; Powell 1990). Absent this analytic separation, as well as the understanding that institutions and organizations flow from deeper levels of social life, everything becomes an undifferentiated mass where the recognition that “institutions matter” leads no further than descriptive statements and, at worst, to tautologies.

The discussion in this section and the accompanying diagram serve to flesh out the five basic points cited previously. First, the causal hierarchy among different components of culture and social structure implies that those factors affecting deeper levels will have much more significant consequences in producing change than those impinging on its surface elements. A successful revolution that upends the power hierarchy of a nation or a charismatic prophecy that transforms its value system will have more far-reaching implications than a decree creating a new government ministry, a new ban on smoking in public places, or a modified curriculum in 
public schools. Second, institutions crystallize prior processes of change at deeper levels of society because they represent the embodiment of existing power arrangements, social classes, values, and skill repertoires.

Third, as "symbolic blueprints” for social organizations, institutions are in constant tension with actual reality so that if role occupants are governed by institutionalized rules, their actions and interactions also affect those rules and often modify their character. These dialectics between institutions and the organizations they govern -- the problem of embeddedness -- occurs at the surface of social life and tends to produce continuous, incremental changes. Social change, at this level, is indeed "ubiquitous". Yet, focusing exclusively on these changes and others occurring at the surface, neglects the continued stability of basic elements of culture and social structure, quite removed from that level and far more resistant to change.

\section{The Concept of Migration}

With this conceptual spadework done, we can turn to the relationship between migration and social change. Migration is, of course, change and it can lead, in turn, to further transformations both in sending and receiving societies. Here I restrict the scope of analysis to migration across national borders, although several of the points made below may apply as well to long-distance domestic movements. As a form of change, international migration has been analyzed as a consequence of a diverse set of causes, both in the source and receiving countries. A number of summaries of this literature already exists (Massey et. al. 1998; Portes and Rumbaut 1996; Sassen 1988), and thus it would be redundant to review it in detail again. For the record, it suffices to list the principal schools that have advanced hypotheses in this area: 
- The neoclassical approach, based on an individualistic calculus of benefits and costs among would-be migrants (Borjas 2001; Thomas 1973).

- The "new economics" approach, based on the concept of relative deprivation and an emphasis on family strategies to overcome capitalist market imperfections in sending regions (Stark 1991; Massey 1990).

- The world-system perspective, grounded on the concepts of structural penetration and "imbalancing" of peripheral areas creating the conditions for mass displacements out of them (Portes and Walton 1981; Sassen 1988; Alba 1978).

- The social networks approach, based on the concepts of "path dependence" and diminishing costs of migration. These concepts are invoked less to explain the origins of migration as its continuation and resilience over time (Tilly 1990; Anderson 1974; Castles 2004.)

As a cause of change, migration has been analyzed from a cultural perspective that emphasizes its potential for value/normative transformation and from a structural perspective that highlights its demographic and economic significance. Studies of change vary in scope, focusing at the micro-level of individuals and families; the meso-level of communities and regions; and the macro-level of nation-states and the global economy (Massey et. al. 1998; Portes 1999). Just as the scope of analysis varies, so does the depth of the processes of change attributed to migration. Effects may simply scratch the surface of society, affecting some economic organizations, role expectations, or norms. On the other hand, they may go deep into the culture, transforming the value system, or into the social structure, transforming the distribution of power. Such profound transformations are precisely what opponents of migration 
in receiving societies fear and what they have traditionally railed against (Grant 1916; Brimelow 1995; Huntington 2004).

The power of migration to effect change either in sending or receiving regions and countries depends on three main factors: a) the numbers involved; b) the duration of the movement; c) its class composition. Concerning the first, it is obvious that small displacements have little causative power, seldom going beyond the lives of those involved and their immediate kin. At the other extreme, "telluric movements" that see an entire people decamp and move to other parts of the planet in search of better future can have dramatic consequences in the places that they leave and in those where they settle. At various points in human history, such displacements have literally redrawn the social and demographic map of the world. The prehistorical cross-Pacific movements that populated the Americas; the "barbarian invasions" that did away with the Roman Empire and redrew the map of Europe; the peopling of Canada, Australia and other settler colonies by the English; the famine-led Irish emigration to North America and elsewhere in the mid-nineteenth century; and the Jewish exodus to Palestine in the mid-twentieth provide so many disparate examples (Braudel [1949] 1973; Pirenne 1970; Goldscheider 1986).

In the United States and Europe today, the fears expressed by opponents of immigration commonly portray a similar "telluric movement" rising out of the poorer nations of three continents and overwhelming the social systems and the culture of the developed world (Lamm and Imhoff 1985; Brimelow 1995). Such fears are readily contradicted by the numbers scarcely 200 million migrants in a planet of 6 billion, with only a minority going to the advanced countries (United Nations 2002) and by the capacity of the host societies to fend off drastic change, a point to which I will return. 
Concerning the second factor, circular flows of short duration tend to produce less durable change than permanent displacements. Under certain conditions, cyclical movements may reinforce the existing social structures rather than change them. This may occur, for instance, when migrant workers' earnings help support the development of rural productive structures at home, thereby strengthening their long-term viability (Stark 1984). Similarly, temporary labor migration to Western Europe in the 1960s and 1970s helped significantly its economic expansion without making much of a dent into European social structures or cultures until the compulsory end of the program turned temporary workers into permanent migrants (Castles and Kosack 1973; Hollifield 2004).

Permanent out-migration can significantly alter the demographic structure of sending societies, as when entire regions are depopulated. Permanent migrants can also have a stronger influence on sending regions by weakening local productive systems, and changing the culture in the direction of out-migration as the sole normative path to upward mobility (Lungo 1999; Delgado-Wise 2007). A settled permanent immigrant population of any size will also have a greater impact in the culture and social structure of host societies, as is evident with the transformation of circular to permanent immigration among Turks, Moroccans, and Algerians to Western Europe and with the end of cyclical labor migration across the U.S.-Mexican border, paving the way for a permanent unauthorized migrant population in the United States (Castles and Kosack 1973; Massey et. al. 2002).

Finally, the third factor - the composition of migrant flows - affects the change potential of migration in unexpected ways. One may argue that movements composed of persons with higher human capital would have a greater impact on receiving societies because of the greater capacity of such migrants to express themselves and protect their cultural traits. In fact, the 
opposite tends to happen because educated migrants have greater flexibility and capacity to adapt to the receiving culture, being often fluent in its language. Greater human capital translates into better opportunities in the labor market and easier entry into the host society's economic mainstream (Hirschman and Wong 1986; Portes and Rumbaut 2006: Ch. 2). That is, in part, why migration of professionals is seldom seen as a problem in the host societies. On the contrary, flows composed of poorly-educated workers can have a more durable impact because of their initial ignorance of the host language and culture and the tendency, especially among migrants from rural origin, to adhere tightly to their customs. Sizable flows of migrant workers tend to give rise to visible cultural-linguistic concentrations, generally in marginal areas of host societies. Such "ghettos" go on to become natural targets for nativists who paint them as tangible evidence of migrants' inferior cultural or even biological endowments (Borjas 2001; Brimelow 1995).

Lastly, flows that are class-diverse -- comprising both high- and low-human capital migrants -- are most likely to give rise to institutionally-complete ethnic enclaves in receiving countries. This is so because skilled immigrants are able to set up enterprises using the mass of their co-ethnics as both a market and a source of labor (Wilson and Portes 1980); in turn, less educated immigrants find in these ethnic enterprises an alternative source of employment opportunities and even a "training mechanism" to learn themselves the ropes of small business management (Zhou and Bankston 1998; Bailey and Waldinger 1991).

Institutionally-complete enclaves represent the most visible manifestation of change wrought on host societies by migration. The duration of such formations varies significantly, however. In the United States, they tend to last no more than two to three generations because the very success of immigrant entrepreneurs pushes their descendants into positions of advantage 
in the host country's economic mainstream (Zhou 1992; Portes and Shaffer 2007). In Germany and other European countries, according to some accounts, immigrant enclaves appear to last longer (Esser 2004).

The archetypical enclave was that created by the Jewish exodus out of Czarist Russia in New York City. At the start of the twentieth century, almost two million Russian Jews migrated to America from the Pale of Settlement where they had been confined by the Czarist regime and where they were subjected to repeated pogroms. Unlike Italians and other migrant workers of the time, Russian Jews were class-diverse. Skilled artisans and merchants abounded among them and they used their resources to set themselves up in business, starting as humble peddlers and gradually rising in the capitalist hierarchy. By the mid-1930s, an institutionally-complete Jewish enclave had developed in the Lower East Side of Manhattan, where religious and cultural institutions proliferated, an ethnic press in English and Yiddish flourished, and where the needle trades became the "great Jewish métier" (Rischin 1962; Howe 1976).

A few years later, children of these now prosperous migrants were literally taking the East Coast universities by assault, with the City University of New York serving as the main focus for their educational and professional aspirations. By the 1960s, the Jewish Lower East Side was a memory, but members of the Jewish third generation had by then become ensconced in the city's upper professional and business ranks, their education and incomes significantly surpassing those of other ethnic groups, including Anglo-Americans (Dinnerstein 1977; Sowell 1981: Ch. 4).

A more contemporary example is provided by the Cuban exodus to Miami. Like the Jewish one, this emigration out of the island was class-diverse, led by the old upper- and middlestrata escaping Castro's revolution. Successively lower layers of the island's population 
followed the elites, all clustering in South Florida. In a few years, an ethnic enclave began to take hold and by the 1990s, it had consolidated into a cultural, religious, and political complex buttressed by over 72,000 Cuban-owned firms. By 2000, the incomes of Cuban exiles arriving in the 1960s and 1970s were at par with those of native whites and those of Cuban business-owners were the highest in the region. The exiles also had the highest rates of self-employment of any ethnic group in the area. Second-generation Cubans, while also displaying high average incomes, had much lower rates of business ownership, an indication that, like the Jewish second generation, they were leaving the original enclave to seek mobility in mainstream professions (Portes and Stepick 1993; Stepick et. al. 2003; Portes and Shaffer 2007).

The pace of cultural and political ascent of Cubans was, if anything, swifter than the early Jewish rise out of Lower Manhattan. Today, Spanish has joined English as the language of business and everyday discourse in Miami. The mayors of all large cities, including Miami proper and Miami-Dade County, are Cuban, as are the area’s three federal congresspersons; Miami’s delegation to the Florida State legislature is almost uniformly Cuban, being comprised of both former exiles and their children.

\section{Migration-Induced Change}

\section{a. Host Societies}

"Immigration has transformed America" is a frequent mantra in the current immigration literature. As a rhetorical device, there is nothing wrong with these statements, but it is time to consider seriously how accurate they are. In a more scholarly vein, Alba and Nee (2003) speak of the ways immigration "remade the American mainstream". Is this really so? In other words, is it the case that migration has transformed core elements of the host societies? Referring to the 
hierarchy of elements in Figure 1, it is evident that truly revolutionary social change requires the "remaking” of the value system and the transformation of a society's class structure. Are migration-induced changes capable of achieving this?

Seldom. It is true, as many authors have asserted, that massive immigration can transform the "sight and smells" of cities, the ethnic composition of the masses riding public transportation or, as Kasinitz et. al. put it in their recent study of New York City: That the city has no clear ethnic majority means that it was "no big deal” for our second generation respondents to have immigrant parents. They rarely felt like outsiders or exotics. Most of their friends were in a similar situation, and anyway, everyone is from somewhere (Kasinitz et. al. 2008: 22).

But these are "street-level" changes. The fundamental pillars of New York society have remained unaltered. These include the legal/judicial complex, the educational system, the dominance of English, the basic values guiding social interaction, and, above all, the distribution of power arrangements and the class structure. As portrayed in Figure 2, mass immigration "pushes from below", affecting certain organizations such as labor-intensive industries and public schools and forcing some institutional accommodations at this level. However, the transformational potential of migration is limited, at every level, by the existing web of institutions reflecting deep cultural and power arrangements. These channel migrants to "proper" places in the status system and educate them and their descendants in the language and cultural ways of the host society. This is what the process of assimilation is about.

At this point, it is necessary to distinguish between the structural significance and the change potential of migration flows. As noted previously, they can be important precisely 
because they buttress the dominant political and economic structures, without so much as a dent made in the existing institutional order. Migration of professionals and technicians can acquire structural significance in furthering the development of high-tech industries; similarly, laborintensive sectors may become structurally dependent on flows of manual workers (Saxenian 2006; Roberts et. al. 1999; Cornelius 1998). These movements help consolidate, not modify, fundamental aspects of the culture and power structure of receiving societies. As we have seen, cyclical movements possess the least change potential because of their very temporariness and precariousness (Piore 1979). Permanent settlements can reach farther, but even in these cases their capacity to effect profound transformations in the host countries is limited.

Unless immigration becomes a "telluric movement” overwhelming the existing structures of power, its capacity to induce profound social change is limited. In order to prevent migration from doing to the receiving societies what the "barbarian invasions" did to Rome, there is a thick institutional web defending the primacy of existing values and normative structures and there is, above all, the state. Modern states are sufficiently powerful to ensure that migration-induced change does not get out of the way and certainly that it does not challenge the core cultural and structural pillars of host countries.

The "assimilative clash" portrayed in Figure 2 certainly has a number of important consequences, but they are not of a revolutionary kind. Leaving aside cyclical movements for the time being, it is a fact that even permanent settlers are unable and, for the most part, unwilling to confront the power of the host state. Instead they seek various forms of accommodation which depend on the third factor noted previously, namely the class composition of each flow. High human capital migrants tend to acculturate rapidly and seek entry into the middle-class mainstream, riding on their occupation skills and cultural resources; manual 
laborers cluster in poor and marginal areas, creating a host of religious, cultural, and sport organizations for comfort and self-defense; class-diverse migrations commonly morph into institutionally-complete enclaves where migrants carve their own path to upward economic mobility.

The presence of these foreign sub-societies frequently catches the eye of nativists and other observers, prompting the assertion that migration is "remaking the mainstream". Nothing of the sort actually happens. Migration can transform the "looks" and the ethnic composition of the working-classes without altering the basic social order. In America, working-class migrant communities effectively disappear with the occupational and residential mobility of the second generation, as it happened to so many "Little Italys" and "Little Polands" that once dotted the Eastern and Midwestern urban landscapes (Alba 1985; Dinnerstein Thomas and Znaniecki 1927: 1511-49). Alternatively, racism and other structural forces may keep the second generation bottled up in the same marginal areas occupied by their parents which then degenerate into urban "ghettos" or "barrios" -- places of permanent subordination and disadvantage (Wacquant and Wilson 1989; Mills 1967; Vigil 2002). For subsequent policy-makers, the problem posed by these areas is precisely how to make them join -- not remake -- the social mainstream (Wilson 1987; Barrera 1980; Bean and Stevens 2003).

As seen previously, ethnic enclaves can represent avenues for mobility. Unless migration from the host society continues, they also tend to disappear in the course of two-three generations. While it is true that Jewish-Americans in their day and Cuban-Americans today escalated to top positions in the class structure of their respective cities, they did so precisely by conforming to the American value/normative complex and its legal system, not by challenging them. Although for local elites displaced from power in a city like Miami, the successive Cuban 
exile waves may have seemed "telluric”, the fact is that the newcomers' ascent took place within the existing institutional rules (Portes and Stepick 1993). Today, the CEO of a large New York corporation may be named Lowenstein rather than Johnston and the mayor of Miami-Dade County may be an Alvarez rather than a King, but the normative order governing the corporation, the county and the broader society in which both are embedded remain largely unchanged and distinctly American.

The assimilative clash in Figure 2 has another important social consequence, namely the activation of nationalistic and patriotic feelings among the host population. Prompted, in part, by the fear that the foreign flow becomes overwhelming, these attacks -- of which Huntington’s "Hispanic Challenge” is the latest exemplar -- have several disparate consequences. On the positive side, they revive patriotic sentiment and, paradoxically, turn the presence of migrants into an occasion for the reaffirmation of national traditions and values. On the negative side, they deeply stigmatize migrants and push those groups least able to defend themselves to the lowest rungs of society’s status system and class structure (Fernández-Kelly and Konczal 2005). These conditions become the prelude for a self-fulfilling prophecy where racism blocks access to mobility channels, creating the basis for downward assimilation in the second generation and the perpetuation of poverty, disadvantage, and deviance (Portes and Zhou 1993; Wacquant and Wilson 1989).

Whether descendants of immigrants end up at the top or at the bottom of the class system, they do not alter its fundamental structure; they simply populate its different layers with new names and new faces. The "diversity” that mass migration brings about consists precisely on the growing presence in existing organizations of new, ethnically-distinct role occupants. Some institutional rules may be changed to accommodate this population - such as making services to 
the public available in various languages. But the public and private institutions that decide to do so and the underlying class system remain untouched. Aside from creating diversity in the streets and building sub-societies at the margin - some as vehicles for upward mobility, others destined to degrade into permanent poverty - the transformative potential of migration is limited. Certain foodways and folkways will undoubtedly filter up and be incorporated into the cultural mainstream, but the bedrock value system and power structure operating through the existing institutional network ensure that whatever "melting” occurs will be decidedly asymmetrical.

\section{b. Sending Societies}

The same distinction between structural importance and change potential of migration flows applies to sending countries and regions. Put differently, in a number of instances these flows may actually strengthen or stabilize the existing socio-political order rather than transform

it. This occurs, for example, when out-migration provides an economic safety valve, alleviating the pressure of popular discontent on elites and allowing them to preserve their privileges (Robinson 1996; Ariza and Portes 2007). A similar effect is associated with the flow of remittances, which may grow to a sufficient size to resolve chronic balance-of-payments problems and even serve as collateral for securing additional external loans (Guarnizo 2003). In such instances, there is no question that migration acquires "structural importance” for the sending country, but its main effect is to consolidate the existing class structures rather than change them in any significant way. This is the reason why many scholars from these nations have rallied against mass out-migration, seeing in it not only an indicator of underdevelopment, but a cause of its perpetuation (Delgado-Wise and Cypher 2007). 
The distinction between circular and permanent outmigration is also relevant here.

Circular flows are less likely to make a dent in the culture and social structure of sending regions because migrant workers are expected to return after a short period abroad. As Stark (1991) and Massey et. al (2002) describe this scenario, the remittances and savings of migrants contribute to overcome the inexistence or imperfection of local credit and futures markets, thereby strengthening the economy of sending regions and facilitating their expansion. The change potential of such flows depends largely on the dominant political regime. Entrenched elites may foster circular migration as a way of alleviating domestic inequalities and poverty, thus helping consolidate the status quo. More progressive regimes may seek to channel migrant remittances and investments in ways that lead to more rapid local development (Gonzalez-Guitierrez 2005; Portes 2007). In either case, the change potential of circular flows are limited by their temporary character which makes their impact felt mostly at the level of sending localities and regions rather than the entire society.

More far-reaching transformations are generally associated with the emergence and consolidation of large expatriate communities. Consequences that follow from mass permanent and semi-permanent outflows are not always positive. While, in some instances, they can bring about significant innovations and infuse local economies with new dynamism; in others, they merely aggravate the problems and imbalances suffered chronically by poor societies. Three such consequences may be cited for illustration.

First, permanent out-migration may end up depopulating entire regions. The pathdependent character of migration generally makes the costs and risks of the journey lower as experience accumulates and as migrant communities consolidate abroad (Tilly 1990; Massey 1987). The continuation of the process over time may remove the very demographic basis for 
development as fewer and fewer able-bodied adults are left behind. As Arias (2008) has recently noted, continuing out-migration from the Mexican countryside has transformed vast areas into semi-empty places no longer seen by authorities as having any developmental potential, but merely as sites for implementation of welfare programs. Similar empirical accounts come from other countries of out-migration, such as Morocco and Turkey (Lacroix 2005).

Second, when not demographically emptied, the culture of sending regions and even the entire nation may be thoroughly transnationalized. This implies that the value system and the pattern of normative expectations become increasingly affected by “imports", in particular those from expatriate communities. In her studies of Brazilian and Dominican migration to the United States, Levitt notes how sending towns and regions have been culturally transformed by the consumer goods, values, and changed cognitive frameworks beamed from the United States. In this fashion, Brazilians and Dominicans become "transnational" without ever having left their own countries.

In Miraflores, villagers often dress in t-shirts emblazoned with the names of businesses in Massachusetts, although they do not know what these words or logos mean. They proudly serve their visitors coffee with Cremora and juice made from Tang...And almost everyone, including older community members, can talk about “La Mozart” or "La Centre” - Mozart Street Park and Centre Street, two focal points of the Dominican community in Jamaica Plain (Levitt 2001: 2-3).

These change-inducing cultural transfers can affect not only towns, but entire countries. In El Salvador, arguably the Latin American nation most affected by this process, researchers 
note that TV news programs often dedicate more time to events occurring in Los Angeles than in the country’s capital (Lungo and Kandel 1999). Levitt (2001) refers to these transfers as “social remittances”. While, as noted previously, consequences may be positive, as conveying healthenhancing information and new technical skills, in other instances the outcome is more dubious. This is especially the case when upward mobility expectations among a country's youths become geared to out-migration, to the neglect of education and the search for occupational opportunities in their own society. Scholars in several sending countries report that young people increasingly "mark time" in adolescence, while waiting for their opportunity to move and live abroad (Arias 2008; Lungo and Kandel 1999; Lopez Castro 2007). Surely, such a disaffected generation is not a good omen for future national development.

Third, and most poignant, is a new and unexpected effect linked to permanent migration that has garnered increasing attention among scholars and policy-makers. Poor migrants who settle permanently abroad tend to bring their families with them, including young children. In the United States, these families settle in marginal areas where children confront a series of barriers to successful adaptation: poor, prison-like schools; racism and discrimination by native teachers and counselors; street violence; and the omnipresence of the drug trade. Such barriers can lead, in a number of cases, to early school abandonment, joining gangs, violent street confrontations, and early arrest and incarceration. These negative adaptation outcomes have been well documented in the research literature and are collectively labeled "downward assimilation” (Portes and Zhou 1993; Portes et. al. 2005; Rumbaut 2005).

Youths undergoing this process can be lost not only to their countries of origin, but to their families and to themselves. As portrayed in Figure 3, the process does not end there. Foreign-born children who have grown in the host society are collectively known as the "1.5 
generation” (Rumbaut 2004). In the United States, members of this generation who have been convicted of a felony are deportable. Many gang members and others who ran afoul of the law have suffered this fate. Once in the country of their parents, these "children of American streets" (Allegro 2006) are commonly forced to fend for themselves. Not surprisingly, they seek to reproduce and implement the same deviant patterns learned during their gang experience. Imbued with the prestige of things American, they commonly impress disaffected local youths and have little difficulty recruiting them. The result is the emergence and proliferation of a gang culture where none existed before (Lungo and Kandel 1999; Boerman 2007).

The so-called "maras" or youth gangs have grown like wildfire in Central American nations and parts of Mexico, terrorizing the citizenry and becoming the number one public security problem in many cities. Commonly neglected in the sudden concern with this problem are two important considerations: First, the phenomenon has its roots in the social context confronted by migrant youths in American society, leading to "downward assimilation”. This concept provides the theoretical linchpin between what happens to migrant families abroad and its repercussions in the countries of origin. Second, deported gang members are a "social remittance”. The enthusiasm awakened by the growth of money remittances by first generation migrants originally led officials and economists in sending countries to overlook what was taking place on the side. At present, the cost of these deportations has come to rival the alleged benefit of economic transfers:

Central Americans are among the national groups with the highest rates of criminal and non-criminal forced removals. While the deportation story largely ends for the U.S. once deportees are sent "home", the impact for receiving nations presents an ongoing 
challenge as new democracies struggle with mounting gang

violence contributed by expatriate youths who were "made in the USA” (Allegro 2006).

The "mara Salvatrucha”, allegedly the most powerful of these transnational gangs, was created in Los Angeles by young Salvadoran migrants as they sought to fend off white racism and defend themselves from attacks by older black and Mexican-American gangs. The transformation that they have wrought in sending societies is a form of migration-induced change, although not one commonly invoked in the theoretical literature. The consequences have been neither positive, nor minor: gangs have literally taken over urban neighborhoods; challenged public security forces in open battles; and created a new, unexpected crisis in countries already struggling with the multiple problems of underdevelopment (Boerman 2007; Grascia 2004).

Figure 3 about here

To balance the picture, there are also positive consequences that expatriate communities can make to sending societies, under certain conditions. One of the most prominent examples are the technological transfers and "know-how" brought by professional migrants to their home countries. These are also "remittances", but of a different kind. They consist of the entrepreneurial and philanthropic activities of high human capital immigrants who, once they have consolidated their own positions abroad, return home either to found new businesses or to support scientific- technological institutions. Saxenian (2006) has conducted an extensive study of what she labels "the new Argonauts" - Chinese, Indian, and Israeli migrant engineers in 
Silicon Valley - who have revolutionized high-tech industry in their own nations. In the process, they have created vast development poles in such cities as Bangalore, India; Hsinchu and Shanghai, China; and Tel Aviv, Israel. The rapid technological development of India and of regions of China in recent years is largely due to the transnational activities of their high-tech expatriates in conjunction with a receptive institutional environment in their home country (Saxenian 2006). Needless to say, such high-tech transfers can have a significant impact on economic development at the national level.

A second potentially positive effect of large expatriate communities consists of their capacity to vote in national elections freed of the clientelistic and coercive pressures commonly applied by political elites to a captive national electorate. Once granted the right to vote from abroad, expatriates can act as a powerful moralizing force and as a potentially decisive political lever. Recent studies of migrant voting in national elections indicate that this potential is still far from being realized (Itzigsohn and Villacrés 2008; Smith 2008). Even when legally entitled to vote, migrants may face so many obstacles to casting their ballots that only a small committed minority do so. Smith (2008) and others suggest that this may be due, at least in part, to the action of entrenched political elites at home fearful of the impact of the expatriate vote on their interests. While so far not implemented, the potential of a large migrant electorate on national politics is still very much there (Itzigsohn and Villacrés 2008; Baubock 2003). Once the right to vote has been conquered, it seems but a matter of time until migrant organizations gear up to make sure that it is actually turned into practice.

Whether positive or negative, migration-induced social change in sending countries and regions tends to be more far-reaching than in host societies. This is due, in large part, to the asymmetrical distribution of economic power, technical know-how, and cultural influence in the 
global system that privileges “core” nations and regions (Arrighi 1994; Hopkins and Wallerstein 1977). By extension, large expatriate communities that have become ensconced in advanced societies acquire, by dint of this fact, an economic, technological, and culture "edge" over those left behind. This edge, plus the relative institutional and organizational weakness of peripheral nations, allows the influence of migrant communities to "reach deeper" into the culture and social structure of their own societies, producing changes beyond the surface level. Naturally, the larger and more resource-endowed migrant communities are, relative to their home nations, the more profound the changes that they can bring about. This is why small countries with large emigrant populations, like El Salvador and the Dominican Republic, have been thoroughly "transnationalized", while larger nations like Mexico, despite sustained emigration, have so far experienced profound social changes primarily at the regional level. Figure 4 summarizes the preceding discussion with a typology of migrations and their effects in both sending and receiving nations.

Figure 4 about here

\section{Conclusion}

This paper has sought to clarify the concept of social change as it has evolved in sociological and political theory; extract basic lessons from its evolution; and relate it to migration, both as an outcome and as a cause. In conclusion, it is worthwhile to highlight the principal conceptual point that has guided my analysis of the change-potential of migration for both sending and receiving nations. This is the notion that society is no level playing field 
formed by a simple aggregation of individuals. On the contrary, it is complex and hierarchical, both in its constitutive elements and in its receptivity or resistance to change-inducing forces.

The level-playing-field view induces a purely demographic analysis of the effects of migration, where the greater the number of persons leaving or arriving, the greater the magnitude of change. This is the kind of analysis leading to the conclusion that "migration is changing the mainstream”, because of the number and diversity of the foreign population. As we have seen, this conclusion is erroneous because it focuses on the visible plane of social life, neglecting more basic structural and cultural factors. At the surface level, the notion that migration is changing the mainstream is readily apparent in the new sights, sounds, smells that a growing foreign population brings along. An informed sociological analysis would reject this conclusion: despite high numbers, migration flows can leave intact and even buttress the fundamental constitutive elements of receiving societies. To affirm that migration is truly transforming them, one would have to demonstrate that its change-inducing potential is reaching such elements. This happens only under exceptional conditions.

A second consideration calls attention to the common evaluative component in analyses of social change. Perhaps out of dislike with entrenched structures of power and sympathy with the plight of the downtrodden, many social scientists tend to see change - especially that of a revolutionary kind - in a positive light. By extension, the change-inducing potential of mass migration is also regarded as a good thing. In reality, change is not always superior to stability and, as the examples considered previously show, population movements can have both positive and negative consequences.

A third methodological consideration has to do with the need of examine the relations between migration and change under a transnational lens because of the increasing boundedness 
of the global system. It is not always the case that migrant populations come to affect host societies “once they settled here” or that they changed the regions of origin "as they left”. On the contrary, the change-potential of migration is often gestated in events that took place “there”, not "here". This is clear in the impact of social remittances in places of origin. As portrayed in Figure 3, the serious public security situation in Central America had its origins in the streets of Los Angeles and among youths that had left with their families many years earlier. Similarly, the displacement of Anglo elites from political power in South Florida and their substitution by Cuban-Americans in the 1980s and 1990s were not due to events in Miami, but to the revolutionary convulsions in the island two decades earlier.

A final issue pertains to the appropriate time frame for the analysis of migration and its consequences. A short-term perspective, focused on the process as it is unfolding will provide rich detail, but may miss out its more durable effects. To cite again the same examples, the rise of the maras as a consequence of migration from El Salvador and elsewhere in Central America unfolded over three decades; the takeover of political power by Cuban middle-class exiles in Miami took about the same time.

On the other hand, a long-term historical lens may also miss out important migrationinduced consequences because they may have been already absorbed into the culture and class structure of society. The assimilationist perspective in migration studies in the United States tends to take this long-term view of the process, making it appear unduly seamless and gradual. In the long term, of course, immigrants assimilate, leave, or die and their imprint is duly absorbed by the institutions of the receiving society. Using this lens, assimilation appears inevitable, but that conclusion ignores the many exceptions, contradictions, and failures that 
happened along the way. As Gans (1992) put it, the process of incorporation of immigrant flows is inevitably "bumpy".

For this reason, a middling time-frame encompassing two-three generations recommends itself. It would not be so immediatist as to miss the forest for the trees; nor so elongated as to miss the many trees that fell by the side as the forest rebuilt itself. This is the reason why it is still too early to pass judgment on the effects of several contemporary flows, including those now arriving in new countries of immigration in Western Europe. Durable effects of such movements, as they evolve in an increasingly transnationalized global system, cannot be determined with certainty at present. As social scientists, we must have the patience to wait and see how they unfold. They may repeat the lessons of the past, as those well charted by the migration of Europeans to America, or they may carve new paths with so far unexpected consequences for the places left behind and those where they have chosen to pursue their lives. 


\section{Figure 1}

\section{The Elements of Social Life}

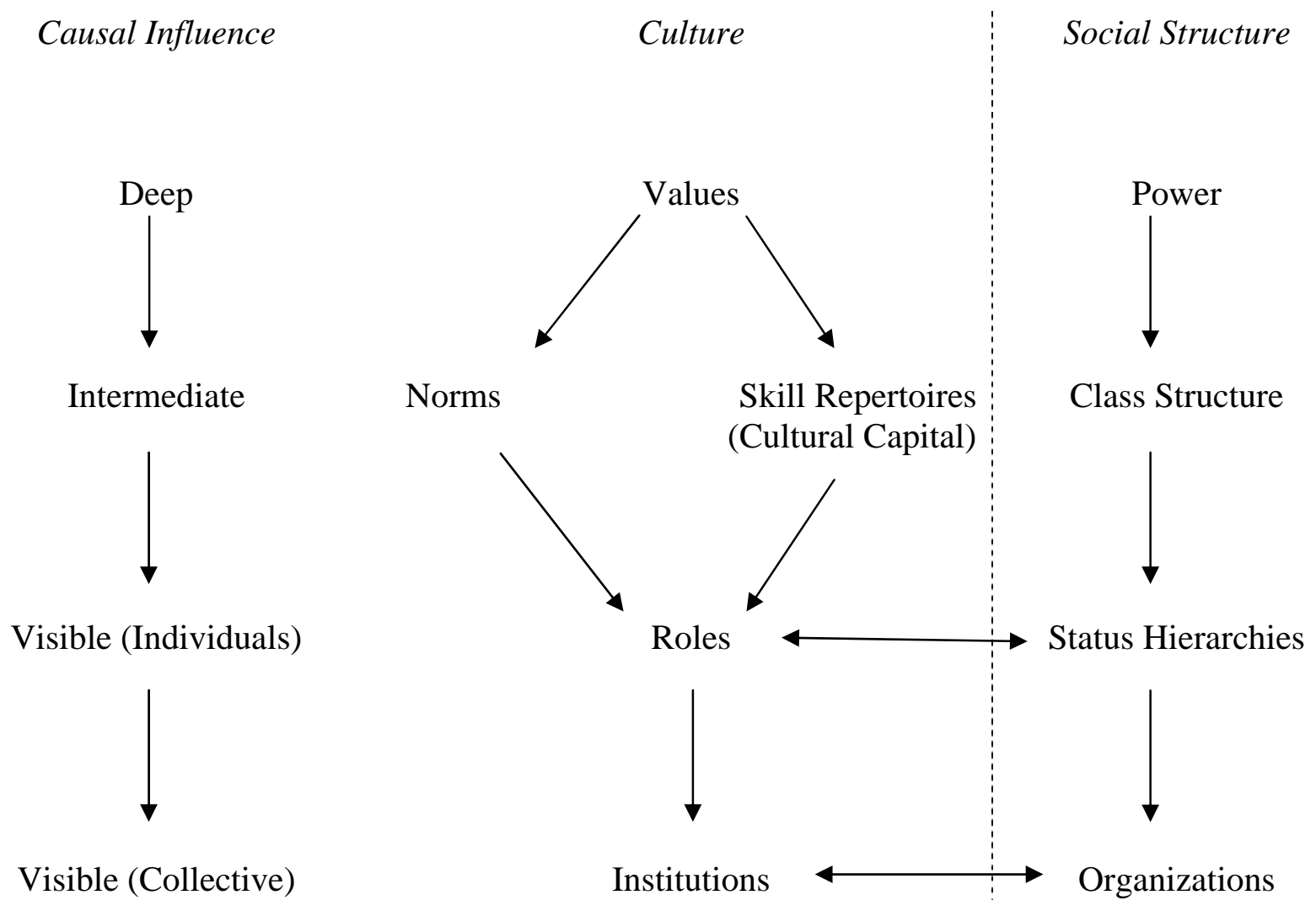




\section{Figure 2}

\section{Migration and Change in Host Societies}

Causal Influence

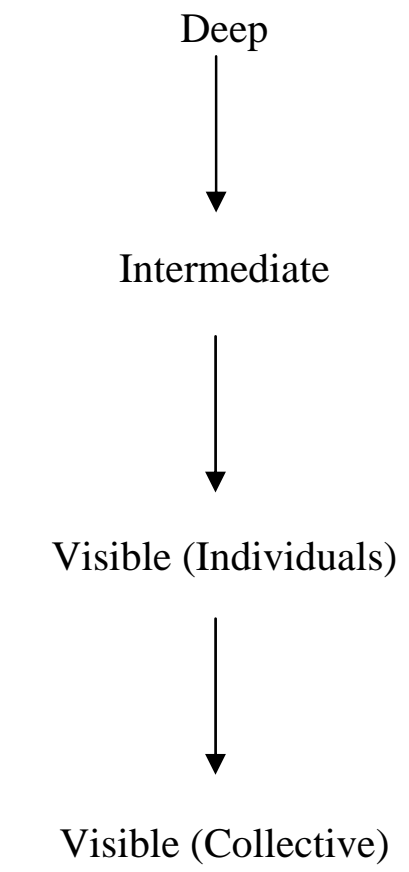

The Assimilative "Clash"
Culture

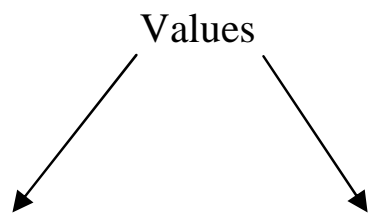

Norms

Skill Repertoires (Cultural Capital)

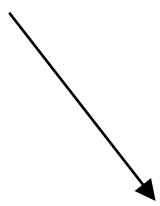

Social Structure

Power

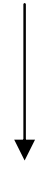

Class Structure

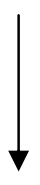

Status Systems

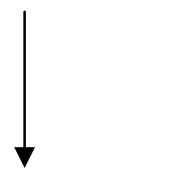

Institutions

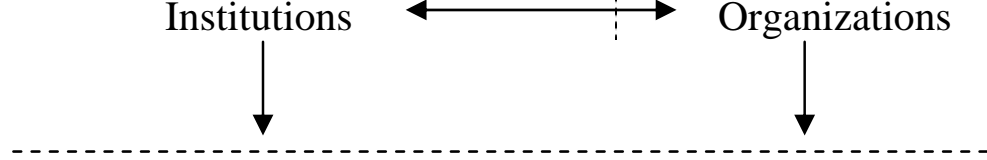

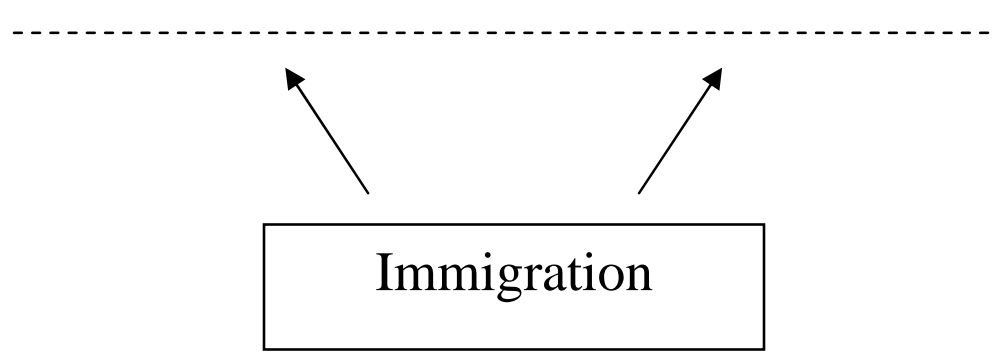


Figure 3

Downward Assimilation in the Second Generation and its Effects on Home Societies

Poverty and civil war leads Central American peasants and workers to emigrate.

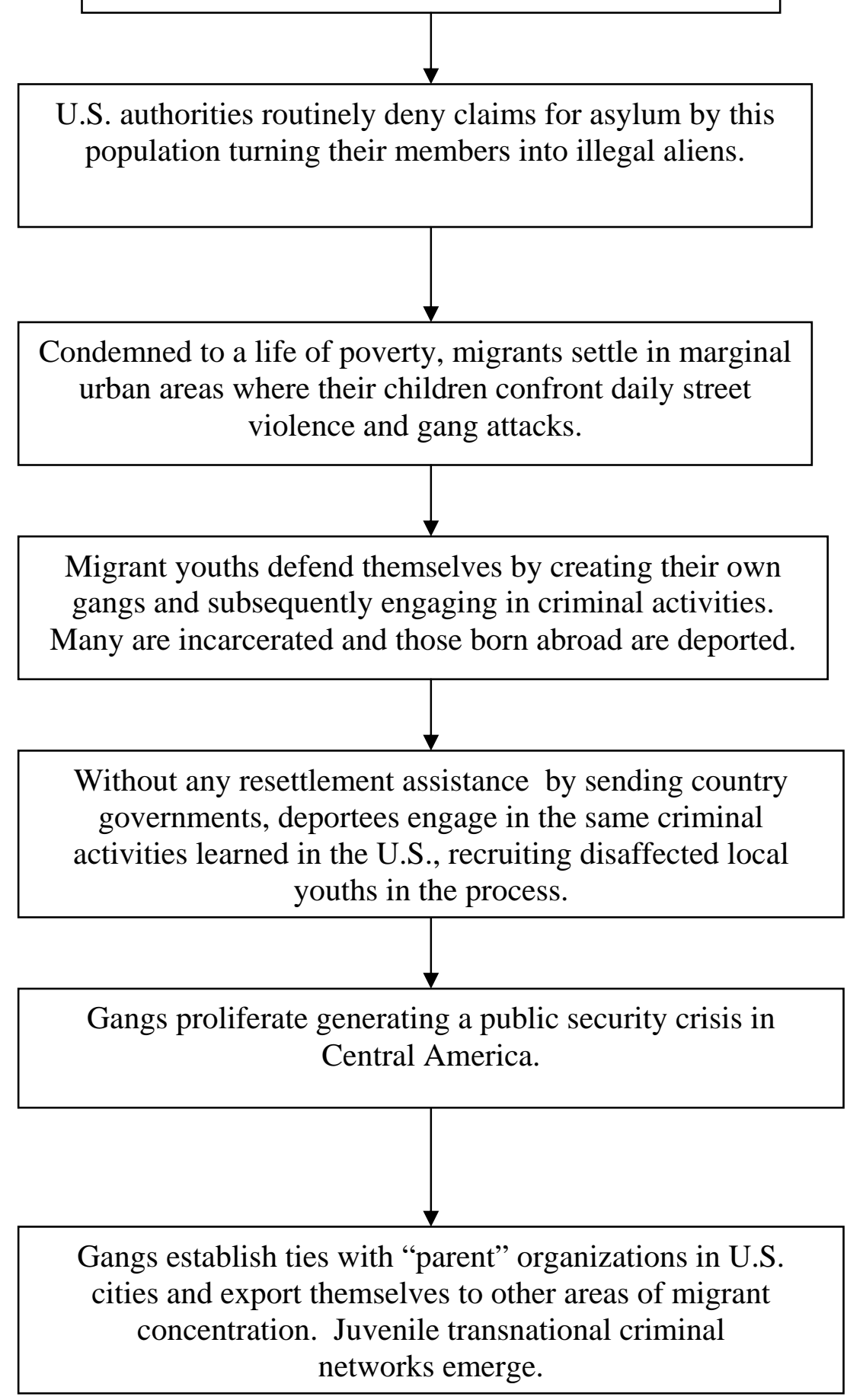


Figure 4

Types of Migration and their Change Potential

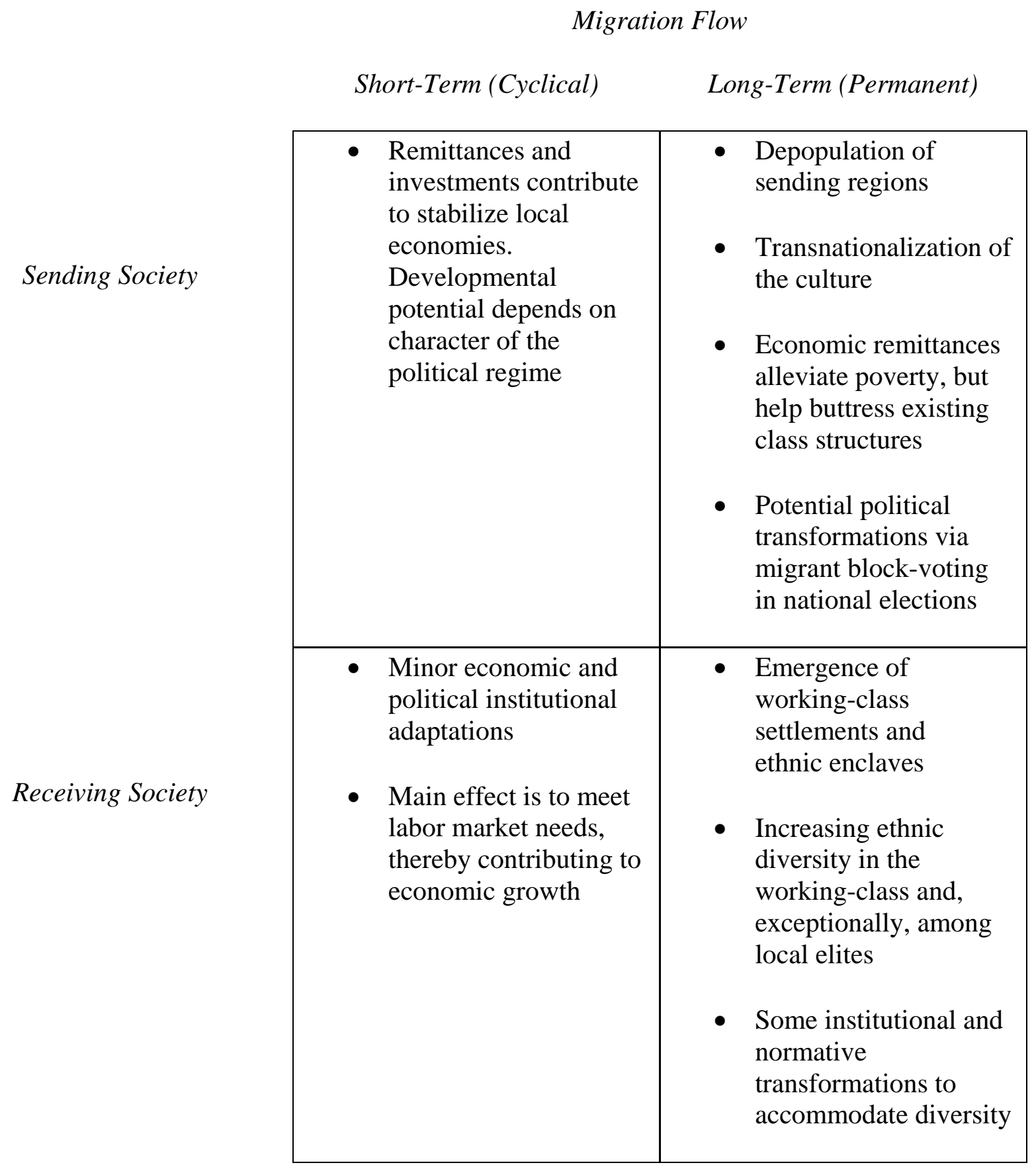




\section{References}

Alba, Francisco. 1978. "Mexico's International Migration as a Manifestation of Its Development Pattern." International Migration Review 12:502-51.

Alba, Richard D. 1985. Italian Americans: Into the Twilight of Ethnicity. Englewood Cliffs, NJ: Prentice-Hall.

Alba, Richard and Victor Nee. 2003. Remaking the American Mainstream: Assimilation and Contemporary Immigration. Cambridge, MA: Harvard University Press.

Allegro, Linda. 2006. “Deportation of 'Illegal Aliens’ under a Neoliberal Security Agenda: Implications for Central America.” Ameriquest (online), Vol. 3, \#1.

Anderson, Grace M. 1974. Networks of Contact: The Portuguese and Toronto. Ontario: Wilfrid Laurier University Press.

Arias, Patricia. 2008. “Mexico’s Rural Agenda: Themes and Dilemmas.” Lecture delivered at the Center for Migration and Development, Princeton University. April.

Ariza, Marina and Alejandro Portes. 2007. “La Migración Internacional de Mexicanos: Escenarios y Desafios de Cara a un Nuevo Siglo.” Pp. 1-51 in El Pais Transnacional, edited by M. Ariza and A. Portes. Mexico DF: IIS/National University of Mexico Press. Arrighi, Giovanni. 1994. The Long Twentieth Century: Money, Power, and the Origins of Our Times. London: Verso Books.

Bailey, Thomas and Roger Waldinger. 1991. "Primary, Secondary, and Enclave Labor Markets: A Training System Approach." American Sociological Review 56:432-45.

Balmes, Jaime. 1961. El Criterio $9^{\text {th }}$ Edition. Barcelona: Editorial Balmesiana.

Barrera, Mario. 1980. Race and Class in the Southwest: A Theory of Racial Inequality. Notre Dame, IN: Notre Dame University Press. 
Baubock, Rainer. 2003. “Toward a Political Theory of Migrant Transnationalism.” International Migration Review 37: 700-723.

Bean, Frank D. and Gillian Stevens. 2003. America's Newcomers and the Dynamics of Diversity. New York: Russell Sage Foundation.

Boerman, Thomas. 2007. "Central American Gangs: An Overview of the Phenomenon in Latin America and the U.S.” Journal of Gang Research 15 (1): 35-52.

Borjas, George J. 2001. Heaven's Door: Immigration Policy and the American Economy. Princeton, NJ: Princeton University Press.

Bourdieu, Pierre. 1990. The Logic of Practice. Stanford: Stanford University Press.

Braudel, Fernand. [1949] 1973. The Mediterranean and the Mediterranean World in the Age of Philip II, Vol. II. New York: Harper Colophon Books.

Brimelow, Peter. 1995. Alien Nation, Common Sense About America's Immigration Disaster. New York: Random House.

Castles, Stephen. 2004. “The Factors that Make and Unmake Migration Policies.” International Migration Review 38 (Fall): 852-884.

Castles, Stephen and G. Kosack. 1973. Immigrant Workers and the Class Structure of Western Europe. London: Oxford University Press.

Collins, Randall. 1988. Theoretical Sociology. New York: Harcourt Brace Jovanovich.

Cornelius, Wayne A. 1998. "The Structural Embeddedness of Demand for Mexican Immigrant Labor: New Evidence from California.” Pp. 115-55 in Crossings, Mexican Immigration in Interdisciplinary Perspective, edited by M. Suarez-Orozco. Cambridge: Center for Latin American Studies, Harvard University.

Coser, Lewis. 1956. The Functions of Social Conflict. New York: Free Press. 
Dahrendorf, Ralf. 1959. Class and Class Conflict in Industrial Society. Stanford, CA: Stanford University Press.

Delgado-Wise Raul and James M. Cypher. 2007. "The Strategic Role of Mexican Labor under NAFTA: Critical Perspectives on Current Economic Integration.” Annals of the American Academy of Political and Social Sciences 610 (March): 120-142.

Dobb, Maurice. [1947] 1963. Studies in the Development of Capitalism. New York: International Publishers.

Fernández-Kelly, Patricia and Lisa Konczal. 2005. “ ‘Murdering the Alphabet’: Identity and Entrepreneurship among Second Generation Cubans, West Indians, and Central Americans.” Ethnic and Racial Studies 28 (November): 1153-1181.

Gans, Herbert. 1992. "Second-Generation Decline: Scenarios for the Economic and Ethnic Futures of the Post-1965 American Immigrants." Ethnic and Racial Studies, 15:173-92.

Goldscheider, Calvin. 1986. Jewish Continuity and Change: Emerging Patterns in America. Bloomington, IN: Indiana University Press.

Grant, Madison. 1916. The Passing of the Great Race or the Racial Basis of European History. New York: Charles Scribner’s Sons.

Grascia, Andrew M. 2004. “Gang Violence: Mara Salvatrucha - Forever Salvador.” Journal of Gang Research 11 (2): 29-63.

Greif, Auner. 2006. Institutions and the Path to the Modern Economy: Lessons from Medieval Trade. New York: Cambridge University Press.

Guarnizo, Luis E. 2003. “The Economics of Transnational Living.” International Migration Review 37(Fall): 666-699. 
Hirschman, Charles and Morrison G. Wong. 1986. "The Extraordinary Educational Attainment of Asian Americans: A Search for Historical Evidence and Explanations." Social Forces 65:1-27.

Hollifield, James. 2004. “The Emerging Migration State.” International Migration Review 38 (Fall): 885-912.

Hopkins, Terence K. and Immanuel Wallerstein. 1977. "Patterns of Development in the Modern World-System." Review 1:111-45.

Howe, Irving. 1976. World of Our Fathers. New York: Harcort, Brace, and Jovanovich.

Huntington, Samuel P. 2004. Who Are We? New York: Simon and Schuster.

Itzigsohn, José and Daniela Villacrés. 2008. “Migrant Political Transnationalism and the Practice of Democracy: Dominican External Voting Rights and Salvadoran Home Town Associations.” Ethnic and Racial Studies 31(May): 664-686.

Kasinitz, Philip, John H. Mollenkopf, Mary C. Waters, and Jennifer Holdaway. 2008. Inheriting the City: The Children of Immigrants Coming of Age. New York: Russell Sage Foundation.

Kincaid, Harold. 1996. Philosophical Foundations of the Social Sciences. Cambridge, UK: Cambridge University Press.

Lacroix, Thomas. 2005. Les Reseaux Maroccains du Developpement. Paris: Presses de la Fondation Nationale de Sciences Politiques.

Lamm, Richard D. and Gary Imhoff. 1985. The Immigration Time Bomb: The Fragmenting of America. New York: Dutton. 
Levitt, Peggy. 2001. The Transnational Villagers. Berkeley, CA: University of California Press.

Lopez Castro, Gustavo. 2007. “Niños, Socialización y Migración a Estados Unidos.” Pp. 545570 in El Pais Transnacional, edited by M. Ariza and A. Portes. Mexico DF: IIS/National University of Mexico Press.

Lungo, Mario and Susan Kandel. 1999. Transformando El Salvador: Migración, Sociedad y Cultura. San Salvador: Fundación Nacional para el Desarrollo.

Mandel, Ernest. 1978. Late Capitalism. London: Verso Books.

Maritain, Jacques. 1960. Filosofia de la Historia. J. Garcia Venturia, ed. Buenos Aires: Ediciones Troquel.

Maritain, Jacques. 1963. Introducción a la Filosofia, Leandro de Sesma, trans. Buenos Aires: Club de Lectores.

Marx, Karl. 1848. The German Ideology. New York: International Publishers.

Marx, Karl. [1869]1963. The Eighteenth Brumaire of Louis Bonaparte. New York: International Publishers.

Massey, Douglas S. 1990. "Social Structure, Household Strategies, and the Cumulative Causation of Migration." Population Index 56:3-26.

Massey, Douglas S., Joaquin Arango, Graeme Hugo, Ali Kouaouci, Adela Pellegrino, and J. Edward Taylor. 1998. Worlds in Motion: Understanding International Migration at the End of the Millennium. Oxford, UK: Clarendon Press.

Massey, Douglas S., Jorge Durand, and Nolan J. Malone. 2002. Beyond Smoke and Mirrors: Mexican Immigration in an Era of Economic Integration. New York: Russell Sage Foundation. 
Merton, Robert K. 1968. "On the History and Systematics of Sociological Theory." Pp. 1-38 in Social Theory and Social Structure. New York: The Free Press.

Mills, C. Wright. 1967. The Puerto Rican Journey: New York's Newest Migrants. New York: Russell \& Russell.

Ortega y Gasset, Jose. 1958. Historia como Sistema. Madrid: Revista de Occidente.

Parsons, Talcott. 1951. The Social System. New York: The Free Press of Glencore.

Parsons, Talcott and Niel J. Smelser. 1956. Economy and Society. New York: Free Press.

Phelan, John L. 1969. “The Problem of Conflicting Spanish Imperial Ideologies in the Sixteenth Century.” Pp. 40-64 in Latin American History: Select Problems, edited by F. B. Pike. New York: Harcourt.

Piore, Michael. 1979. Birds of Passage. Cambridge, MA: Cambridge University Press.

Pirenne, Henri. 1970. Medieval Cities: Their Origins and the Revival of Trade. Princeton, NJ: Princeton University Press.

Portes, Alejandro. 1976. "Determinants of the Brain Drain." International Migration Review 10:489-508.

Portes, Alejandro. 1999. "Immigration Theory for a New Century: Some Problems and Opportunities.” Pp. 21-33 in The Handbook of International Migration: The American Experience, edited by C. Hirschman, P. Kasinitz, and J. DeWind. New York: Russell Sage Foundation.

Portes, Alejandro. 2006. "Institutions and Development: A Conceptual Re-Analysis.” Population and Development Review 32 (June): 233-262.

Portes, Alejandro. 2007. “Un Dialogo Norte-Sur: El Progreso de la Teoria en el Estudio de la Migración Internacional y Sus Implicaciones.” Pp. 651-702 in El País Transnacional: 
Migración Mexicana y Cambio Social a Través de la Frontera, edited by M. Ariza and A. Portes. Mexico, DF: Instituto de Investigaciones Sociales, Universidad Nacional Autonoma de Mexico.

Portes, Alejandro, Patricia Fernandez-Kelly, and William Haller. 2005. “Segmented Assimilation on the Ground: The New Second Generation in Early Adulthood.” Ethnic and Racial Studies 28 (November): 1000-1040.

Portes, Alejandro and Rubén G. Rumbaut. 2006. Immigrant America: A Portrait, $3^{\text {rd }}$ edition. Berkeley: University of California Press.

Portes, Alejandro and Steven Shafer. 2007. "Revisiting the Enclave Hypothesis: Miami Twenty-Five Years Later.” Research in the Sociology of Organizations 25: 157-190.

Portes, Alejandro and Lori D. Smith. 2008. "Institutions and Development in Latin America: A Comparative Study.” Studies in Comparative and International Development 43 (Summer): 105-128.

Portes, Alejandro and Alex Stepick. 1993. City on the Edge: The Transformation of Miami. Berkeley: University of California Press.

Portes, Alejandro and John Walton. 1981. Labor, Class, and the International System. New York: Academic Press.

Portes, Alejandro and Min Zhou. 1993. "The New Second Generation: Segmented Assimilation and Its Variants Among Post-1965 Immigrant Youth." The Annals of the American Academy of Political and Social Sciences 530:74-96.

Rischin, Moses. 1962. The Promised City: New York Jews 1870-1914. Cambridge, MA: Harvard University Press. 
Roberts, Bryan R., Reanne Frank and Fernando Lozano-Asencio. 1999. “Transnational Migrant Communities and Mexican Migration to the United States.” Ethnic and Racial Studies 22 (March):238-66.

Robinson, William. 1996. Promoting Polyarchy: Globalization, U.S. Intervention, and Hegemony. Cambridge, UK: Cambridge University Press.

Rumbaut, Rubén G. 2004. “Ages, Life Stages, and Generational Cohorts: Decomposing the Immigrant First and Second Generations in the United States.” International Migration Review 38 (Fall): 1160-1205.

Rumbaut, Rubén G. 2005. “Turning Points in the Transition to Adulthood: Determinants of Educational Attainment, Incarceration, and Early Childbearing among Children of Immigrants.” Ethnic and Racial Studies 28 (November): 1041-1086.

Sassen, Saskia. 1988. The Mobility of Labor and Capital: A Study in International Investment and Labor Flow. New York: Cambridge University Press.

Saxenian, Annalee. 2006. The New Argonauts: Regional Advantage in a Global Economy. Cambridge, MA: Harvard University Press.

Smith, Robert C. 2008. “Contradictions of Diasporic Institutionalization of Mexican Politics: The 2006 Migrant Vote and Other Forms of Inclusion and Control.” Ethnic and Racial Studies 31(May): 708-741.

Stark, Oded. 1984. "Migration Decision Making." Journal of Development Economics, 14:25159.

Stark, Oded. 1991. The Migration of Labour. Cambridge, UK: Basil Blackwell.

Stepick, Alex, Guillermo Grenier, Max Castro, and Marvin Dunn. 2003. This Land Is Our Land: Immigrants and Power in Miami. Berkeley: University of California Press. 
Stinchcombe, Arthur. 1968. Constructing Social Theories. New York: Harcourt, Brace, and World.

Thomas, Brinley. 1973. Migration and Economic Growth: A Study of Great Britain and the Atlantic Economy. Cambridge: Cambridge University Press.

Thomas, William I. and Florian Znaniecki. 1927. The Polish Peasant in Europe and America, Volume II. New York: Alfred A. Knopf.

Tilly, Charles. 1990. "Transplanted Networks." Pp. 79-95 in Immigration Reconsidered: History, Sociology, and Politics, edited by V. Yans-McLauglin. New York: Oxford University Press.

United Nations. 2002. World Population Prospects: The 2000 Revision. New York:

Department of Economics and Social Affairs, Population Division.

Vigil, Jaime D. 2002. A Rainbow of Gangs: Street Cultures in the Mega-City. Austin, TX: University of Texas Press.

Wacquant, Loic and William J. Wilson. 1989. "The Cost of Racial and Class Exclusion in the Inner City." Annals of the American Academy of Political and Social Science 501:8-26.

Weber, Max. [1904]1949. The Methodology of the Social Sciences. Translated by E. A. Shils and H. A. Finch. New York: The Free Press.

Wilson, Kenneth and Alejandro Portes. 1980. "Immigrant Enclaves: An Analysis of the Labor Market Experiences of Cubans in Miami.” American Journal of Sociology 86 (September): 295-319.

Wilson, William J. 1987. The Truly Disadvantaged: The Inner City, the Underclass, and Public Policy. Chicago: University of Chicago Press. 
Zhou, Min. 1992. New York's Chinatown: The Socioeconomic Potential of an Urban Enclave. Philadelphia: Temple University Press.

Zhou, Min and Carl Bankston. 1998. Growing up American: How Vietnamese Immigrants Adapt to Life in the United States. New York: Russell Sage Foundation. 